\title{
EFFECT OF PERENNIAL RYEGRASS DENSITY ON RAGWORT EMERGENCE
}

\author{
M.L. ARMSTRONG ${ }^{1}$, S.S. SEEFELDT ${ }^{2}$ and K.C. HARRINGTON ${ }^{3}$
}

${ }^{1}$ AgResearch, Ruakura Research Centre, Private Bag 3123, Hamilton

${ }^{2}$ US Sheep Experiment Station, HC 62 Box 2101 Dubois, Idaho 83423 USA

${ }^{3}$ Institute of Natural Resources, Massey University, PB 11222, Palmerston North

Corresponding author: $m \_$armstrong_nz@hotmail.com

\begin{abstract}
The effect of the density of perennial ryegrass (Lolium perenne) swards on the emergence of ragwort (Senecio jacobaea) was investigated in the field and in trays. Ragwort seeds were sown into established perennial ryegrass and white clover (Trifolium repens) swards, and the seedlings were mapped at intervals to aid in identification of new seedlings. In the trays, seedlings were counted and mapped at four week intervals and the experiment was continued for four months. In the field plots, ragwort seedlings were counted before and after each grazing. There was no evidence for any negative effect of ryegrass tiller density on the number of ragwort seedlings emerging. The presence of white clover in trays, and clover and volunteer weeds in the field also provided competition for ragwort.

Keywords: Senecio jacobaea, Lolium perenne, emergence, competition, pasture density.
\end{abstract}

\section{INTRODUCTION}

Ragwort is a troublesome weed on New Zealand dairy and bull beef farms. Its competitive ability and toxicity to cattle allow it to dominate many pastures (Wardle 1987), so herbicides are often applied to control it. Previous studies have suggested that good pasture cover can inhibit the emergence of ragwort seedlings (Poole \& Cairns 1940; Phung \& Popay 1981; Beskow et al. 1994). Thus ragwort will often establish at the same time as sown pasture species in new pastures because of the lack of competition.

To eliminate the need to apply herbicides to young pastures for ragwort control, Seefeldt \& Armstrong (2000) investigated increasing the sowing rate of perennial ryegrass. They found no effect of sowing rate on weed emergence during the first year, due to the minimal competitive ability of emerging grasses. This paper will investigate whether increasing ryegrass sowing rates will assist with ragwort control once the pasture has established.

\section{Field experiment}

\section{MATERIALS AND METHODS}

An experiment was established at the Ruakura Research Centre on 14 April 1999 in a paddock which had been in kale (Brassica oleracea) the previous year. The site was ploughed and harrowed before seeding, and rolled after seeding. The treatments were perennial ryegrass (cv. Bronsyn) sown at $0,5,10,20,40$ or $80 \mathrm{~kg}$ seed/ha. All plots (including 0) were also sown with $5 \mathrm{~kg} / \mathrm{ha}$ of white clover seed (50:50 mix of cv. Sustain and Aran). Plots were $3 \mathrm{~m} \times 7 \mathrm{~m}$ and the treatments were arranged in a randomised complete block design, with four replicates. Emerging volunteer plants were left in the plots to mimic a realistic pasture situation. The plots were grazed every 5-6 weeks by Jersey calves.

New Zealand Plant Protection 54:111-115 (2001) 
On 18 April 200012 months after sowing, a sub-plot measuring $200 \mathrm{~mm}$ x $250 \mathrm{~mm}$ was located at random in each plot, permanently marked, and sown with 500 ragwort seeds. Seed was evenly scattered by hand. In the same week, ten cores (each $50 \mathrm{~mm}$ diameter) were taken at random from each plot and for each core, perennial ryegrass tillers, white clover growing points, weed surface area, and tillers of volunteer grasses were counted. Immediately before and after every grazing the position of each individual ragwort seedling was mapped to enable detection of new seedlings. The experiment continued for 7 months (until 22 November 2000) by which time most ragwort seedlings had disappeared.

Tray experiment

In September 1999, perennial ryegrass (cv. Bronsyn) was sown into polystyrene trays at rates of $0,5,10,20,40,80,160$ or $320 \mathrm{~kg}$ seed/ha. All trays (including 0 ) were also sown with $5 \mathrm{~kg} / \mathrm{ha}$ of white clover seed (50:50 mix of cv. Sustain and Aran). The trays measured $540 \times 340 \times 80 \mathrm{~mm}$ deep and were filled with Horotiu silt loam soil (organic C $6.2 \%$, sand $58 \%$, clay $15 \%$, silt $27 \%$ ). The trays were watered as required and fertilised weekly with Long Ashton nutrient solution (Hewitt 1966). After 50 days in the glasshouse the trays were placed outside. The swards were trimmed monthly to a height of $30 \mathrm{~mm}$ using electric hand shears and all volunteer weeds were removed. Slug bait (Mesurol, active ingredient $20 \mathrm{~g} / \mathrm{kg}$ methiocarb at $10 \mathrm{~kg} / \mathrm{ha}$ ) was applied at monthly intervals.

Perennial ryegrass tillers and white clover growing points were counted on 18 May 2000 in a $50 \mathrm{~mm} \times 200 \mathrm{~mm}$ quadrat in each tray to estimate pasture composition. In the same week, 500 ragwort seeds were evenly scattered onto the soil surface in the centre of each tray, leaving an unsown $60 \mathrm{~mm}$ buffer around the outside of each tray. At monthly intervals, immediately after trimming, all emerged weed seedlings were mapped to aid identification of new seedlings. All seedlings were counted and removed on 5 October 2000 , about 4 months after ragwort seed was sown.

\section{Field Experiment}

\section{RESULTS}

Higher sowing rates of perennial ryegrass seed led to higher tiller densities 12 months later when the ragwort seeds were sown. However, at higher seeding rates the numbers of tillers tended to level off as rates increased. In the field plots with low sowing rates, white clover, other grasses or weeds were present in higher number than the plots with higher sowing rates (Table 1). Variability in tiller numbers was higher in the field plots than in the tray experiment.

TABLE 1: Botanical composition of swards in the field experiment at time of ragwort sowing. Data, except weeds, backtransformed from square root scale.

\begin{tabular}{lccccccc}
\hline & \multicolumn{8}{c}{ Sowing rate of perennial ryegrass } & $(\mathrm{kg} / \mathrm{ha})$ & \\
Species & 0 & 5 & 10 & 20 & 40 & 80 & SED $^{4}$ \\
\hline Ryegrass $^{1}$ & 524 & 676 & 1253 & 2294 & 2144 & 3721 & 825 \\
White clover $^{2}$ & 2894 & 2391 & 2981 & 3260 & 1648 & 864 & 724 \\
Weeds $^{3}$ & 3.8 & 4.9 & 0.6 & 0.4 & 0.3 & 0.6 & $*$ \\
Other grasses $^{1}$ & 1376 & 437 & 515 & 132 & 384 & 3 & 339 \\
\hline
\end{tabular}

${ }^{1}$ Tillers $/ \mathrm{m}^{2} \quad{ }^{2}$ Growing points $/ \mathrm{m}^{2} \quad{ }^{3}$ Percentage surface area

${ }^{4}$ Standard error of the difference between the means.

* Not analysed due to zeros. 
A linear regression of ragwort emergence and ryegrass tiller density indicated there was no significant relationship when all data was included in the analysis (Fig. 1). However, removal of an outlier (77 seedlings, 1019 tillers $/ \mathrm{m}^{2}$ ) gave a statistically significant trend $(\mathrm{P}<0.05)$ which accounted for $22.8 \%$ of the variation in the data. It could be argued that the two data points at the highest tiller densities ( 47 seedlings, 5602 tillers $/ \mathrm{m}^{2}$ and 21 seedlings, 6518 tillers $/ \mathrm{m}^{2}$ ) are also outliers. Removal of these resulted in a more significant trend $(\mathrm{P}<0.01)$ and accounted for $37.9 \%$ of the variation in data.

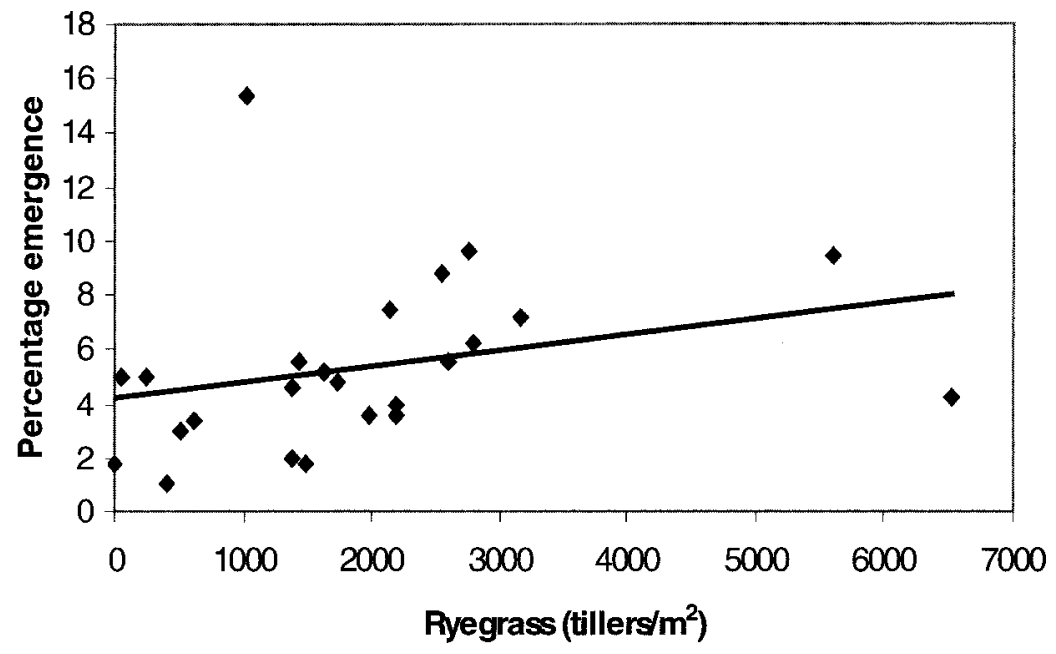

FIGURE 1: Ragwort emergence (\% of sown seeds) in the field experiment at differing perennial ryegrass density.

\section{Tray Experiment}

The leveling off of perennial ryegrass tillers at the higher sowing rates was more pronounced in the trays than in the field, because of the higher seeding rates used in the trays. The data for the trays indicate that at the lower sowing rates white clover was present in higher numbers than at the higher sowing rates (Table 2.)

TABLE 2: Effect of sowing rate on the density of perennial ryegrass and white clover in trays at time of ragwort sowing.

\begin{tabular}{lccccccccc}
\hline \multirow{2}{*}{ Species } & & \multicolumn{8}{c}{ Sowing rate of perennial ryegrass $(\mathrm{kg} / \mathrm{ha})$} \\
& 0 & 5 & 10 & 20 & 40 & 80 & 160 & 320 & SED $^{3}$ \\
\hline Ryegrass $^{1}$ & 0 & 2975 & 4650 & 5500 & 8475 & 8775 & 10350 & 13700 & 1509 \\
White clover $^{2}$ & 3600 & 1550 & 1450 & 550 & 1025 & 575 & 675 & 300 & 310 \\
\hline
\end{tabular}

${ }^{1}$ Tillers $/ \mathrm{m}^{2} \quad{ }^{2}$ Growing points $/ \mathrm{m}^{2} \quad{ }^{3}$ Standard error of the difference between the means.

In the tray experiment the number of ragwort seedlings tended to increase with higher density of ryegrass tillers. A significant $(\mathrm{P}<0.01)$ positive relationship was found between tiller counts and ragwort seedling emergence in the tray experiment (Fig. 2). 


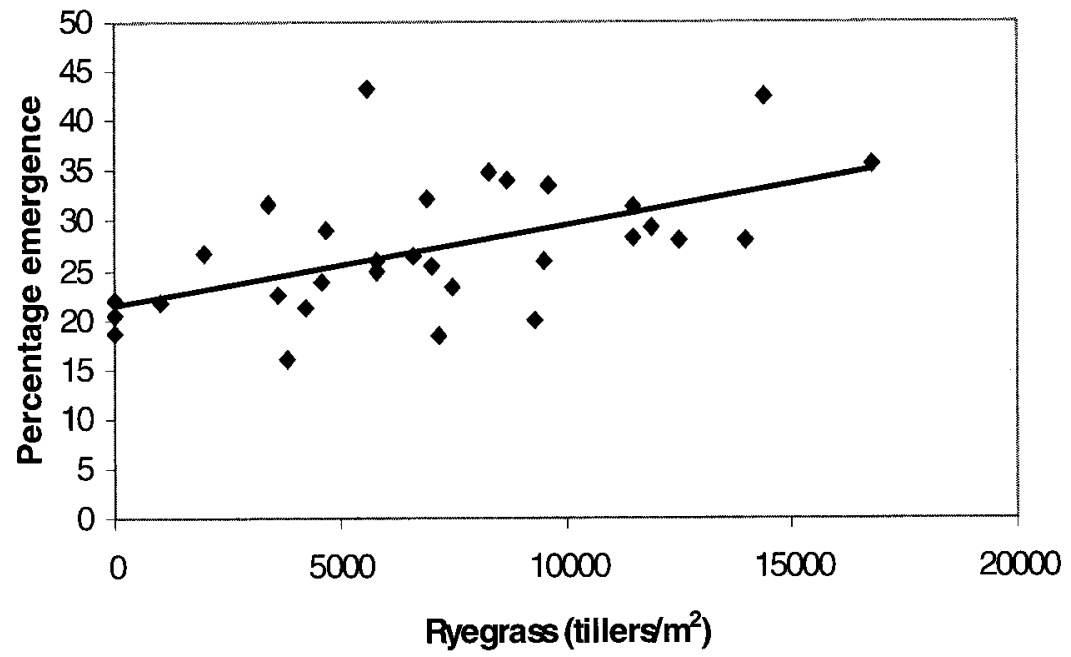

FIGURE 2: Ragwort emergence ( $\%$ of sown seeds) in the tray experiment at differing perennial ryegrass density.

\section{DISCUSSION}

Our results indicate that as perennial ryegrass sward densities increased in an established pasture, ragwort emergence either increased or was unaffected by ryegrass tiller density. This is contrary to the conclusion that many other authors have drawn from similar experiments (Poole \& Cairns 1940; Phung \& Popay 1981; Beskow et al. 1994). However, these authors have tended to focus on the differences between a dense pasture cover and bare ground. Other authors who have investigated different pasture sowing rates, only concentrated on weed emergence and growth soon after the pasture was sown (Cullen \& Meeklah 1959; Seefeldt \& Armstrong 2000). Our study concentrated on the effects of established perennial ryegrass pasture, sown at different densities, on ragwort emergence.

Increases in ryegrass density did not result in a decrease in ragwort emergence. However, one would expect that survival of ragwort seedlings in the higher density plots would be lower. If this is the case, then over time, a dense perennial ryegrass sward could encourage depletion of ragwort from the seedbank as seed germinates at the same rate in all densities of ryegrass but is prevented from flowering in the higher density plots through greater competition.

In our experiment, white clover was sown in both the field and trays at a rate of $5 \mathrm{~kg} / \mathrm{ha}$. Twelve months later when the ragwort seeds were introduced to the plots, the amount of clover present in the plots varied widely due to competition (or lack of it) from ryegrass. In the low ryegrass plots, clover grew to cover the plots and provided competition against the emerging ragwort seedlings. In addition, to create a realistic pasture situation, volunteer weeds and grasses were not removed from the field plots. The result of this after 12 months was a large amount of vegetation other than ryegrass present in the plots with low ryegrass sowing rates. Both the volunteer species and the clover would have affected the emerging ragwort seedlings. Therefore, it could be argued that the plant density was similar in all plots, due to infill in plots with low sowing rates and selfthinning in high sowing rate plots. The significant increase in ragwort emergence at higher ryegrass densities (and lower densities of other species) therefore suggests that the competitive pressure exerted by other species may be an important factor. Ryegrass 
alone may not reduce ragwort emergence as much as other weeds or white clover. It has been suggested by Harper \& Wood (1957) that in the seedling stage, clover is a stronger competitor against ragwort than grasses because clover has a more similar growth habit to that of ragwort.

In conclusion, the trends observed in both the field and trays suggest that under some circumstances more ragwort seedlings can emerge under high density ryegrass swards than low density swards. However, given the self-thinning of ryegrass at high sowing rates and strong growth by white clover and unsown plant species at the lower sowing rates, competitive pressures against new weed seedlings, such as ragwort in the second year after sowing, are probably similar regardless of the initial sowing rate. The positive correlation between ragwort emergence and tiller density suggests that white clover and other species growing at the lower sowing rates are more competitive against ragwort than ryegrass. Thus in the second year after pasture sowing there appears to be no advantage in increasing sowing rates of ryegrass above the normal rates of $20-30 \mathrm{~kg} / \mathrm{ha}$ (Charlton \& Stewart 2000), with regard to reducing levels of ragwort emergence. Note however, that data presented in this paper deals only with seedling emergence, not subsequent growth and survival of the seedlings.

\section{ACKNOWLEDGEMENTS}

Funding for this project was provided by the New Zealand Foundation for Research, Science and Technology. The authors would like to thank John Waller for help with statistical analyses and Ian Popay for advice and discussion.

\section{REFERENCES}

Beskow, W.B.; Harrington, K.C.; Betteridge, K.; Beskow, A.M. da S. 1994: Field studies of ragwort establishment. Proc. 47 $7^{\text {th }}$ N.Z. Plant Prot. Conf: : 49-52.

Charlton, D.; Stewart, A. 2000: Pasture and forage plants for New Zealand. New Zealand Grassland Association, Palmerston North. 74 p.

Cullen, N.A.; Meeklah, F.A.H. 1959. Seeding rates and weedkillers in pasture weed control. Proc. $36^{\text {th }}$ N.Z. Weed and Pest Control Conf.: 54-58.

Harper, J.L.; Wood, W.A. 1957: Biological Flora of the British Isles - Senecio jacobaea L. J. Ecol. 45: 617-637.

Hewitt, E. J. 1966: Sand and water culture methods used in the study of plant nutrition. Commonwealth Bureau of Horticulture and Plantation Crops Technical Communication No. 22.

Phung, H.T.; Popay, A.I. 1981: Effect of pasture cover on the germination of certain weed seeds. Proc. 34th N.Z. Weed and Pest Control Conf.: 111-113.

Poole, A.L.; Cairns, D. 1940: Biological aspects of ragwort (Senecio jacobaea L.) control. Department of Scientific and Industrial Research Bulletin No. 82. Government Printer, Wellington, New Zealand. Pp. 10-27.

Seefeldt, S.; Armstrong, M. 2000: Impact of perennial ryegrass seeding densities on weed emergence, growth and development. N.Z. Plant Prot. 53: 38-43.

Wardle, D.A. 1987: The ecology of ragwort (Senecio jacobaea L.) - A review. N.Z. J. Ecol. 10: 67-76. 